\title{
Economic okra plant act as a preventive-COVID- 19 vaccine advanced horticulture agriculture environment biodiversity conservation science technology communication applications issues
}

\begin{abstract}
The most 'Economically-Important Number-One Consumption-Vegetable-Crops,' is lost by different pathogens like nematodes, causing the root-knot disease which is definitely controlled by different chemical-pesticides, and on the opposite hand, the pandemic coronavirus 2 (SARS-CoV-2) outbreaks of Coronavirus disease 2019 (COVID-19) have emphasized the vulnerability of human populations to novel viral pressures, causing an emergent global pandemic and badly impacts on horticulture-agriculture-environment health socio-economy medical-pharmaceutical science-technology communication issues. So it's an urgent have to develop potential epidemiological and biomedical preventing COVID-19 vaccines. And India emphasis on okra, the 'Nature's-Gift to Human-DiseaseFree-Healthy-Life', and therefore the ultra-high-diluted biomedicines prepared from okra root, applied and confirmed by foliar spray@20 ml/plant each group respectively, are highly effective against the root-knot disease of okra, with increasing fresh-plant growth and fruit production. The high-diluted-biomedicines of okra, are simpler than the untreated ones and show the foremost potential confirmed end in all respects. The genetic-effects of ultra-high-diluted-biomedicines thought to induce systemic acquired resistance response of the treated plants through the expression of pathogenesis-related -proteins-genes (22 to 4 numbers), which are more or less similar molecular range (295kD to $11 \mathrm{kD})$ of the many coronaviruses, and it'll to blame for preventing root-knot and COVID-19 like variantvirus diseases by inducing defense-resistance or increasing innate-immunity, with the toxicfree world, and it should help to develop best potential new preventive treatments methods or drug or vaccines, within the field of " 21 st Century COVID-19 sort of a pandemic within the new normal situation in future, and confirms the "Economic okra Act as a PreventiveCOVID-19 Vaccine Advanced Horticulture Agriculture Environment Biodiversity Conservation Science Technology-Communication Applications", and whole plant act as 'Nature's-Gift Preventive-COVID-19 Vaccine for All'.
\end{abstract}

Keywords: okra, preventive-COVID-19-vaccine, advanced-horticulture-agriculture, environment-biodiversity-conservation, science-technology-communication-applications
Volume 5 Issue 5 - 202I

\begin{abstract}
Subhas Chandra Datta ${ }^{1,2}$
'PhD \& Research Fellow, Department of Zoology,VisvaBharati, Santiniketan-73|235, West Bengal, India

${ }^{2}$ Headmaster \& Secretary, Kanchannagar D.N.Das High School (HS), Kanchannagar, Burdwan Municipality, Purba Bardhaman, Burdwan-7|3|02, West Bengal, India

Correspondence: Subhas Chandra Datta, Headmaster\& Secretary of Kanchannagar D N Das High School (HS), C/O Rajendra Nath Nag, House No.430A, Bajeprotappur (Katwa Road), Opposite to entry of SBI Bajeprotappur, 24 No.Ward, Burdwan Municipality, P O Burdwan, Dist Purba Burdwan, PIN 7|3|0I, West Bengal, India, Tel +91-9832192464, +91-7602303924, Email dattasubhas@rediffmail.com, subhaschandra.datta@gmail.com
\end{abstract}

Received: July 28, 2021 | Published: December 17, 202|

\section{Introduction}

Background of the problems: The recent coronavirus 2 (SARSCoV-2), is just one of the nonillions of viruses on our planet, and scientists are rapidly identifying legions of the most recent species that confronting our next National Health Disaster - long-haul Covid-19, and the outbreaks of Coronavirus disease 2019 (COVID-19) pandemic have emphasized the vulnerability of human populations to novel viral pressures and genome variation of worldwide, causing an emergent global pandemic, and it badly impacts on agricultureenvironment-health-socio-economy medical-pharmaceutical-sciencetechnology-communication-issues, etc. ${ }^{1-22}$

India emphasis on okra (lady finger) for the 'food security', and it is the most important and crucial aspect of sustainable development in the agricultural sector and the backbone of the economy, and it badly effects or influences of the COVID-19 pandemic on food security, agriculture, massive consequences on health and livelihoods of the developing countries. ${ }^{23}$ It is not only reduced incomes, but also disrupted supply chains, chronic and acute hunger due to various factors including conflict, socio-economic conditions, natural hazards, climate change, and pests like the locust which outbreak compounding this crisis across 23 countries with the other zoonotic diseases remain a recurrent threat. ${ }^{24}$ And it is reported that the okra is one the most economically important, commercially exploited, number one consumption in a variety of ways vegetable crops. ${ }^{25}$ Okra is the oldest widely cultivated oligo purpose, significantly contribute for nutritional, medicinal and industrial application, ${ }^{26}$ and used as traditional medicine, achieving the 'Nature's Gift to human disease-free healthy life' multipurpose crop, ${ }^{15,19,20,27-29}$ achieving India first in the world for the fruits rich in vitamins, calcium, folic acid, carbohydrates, phosphorus, magnesium and potassium, iodine, mineral matters, and a good source of superior nutritional quality for human nutrition for preventing different diseases; like cardiovascular disease, type 2 diabetes, kidney diseases, skin infection, digestive diseases, some cancers, antioxidant, nootropic, eye, body immunity, blood pressure, obesity, asthma, constipation, heart disease, sexual health, and neurological disorders, etc., and mature fruit and stems contain crude fiber, used in the paper industry and sugarcane industry. ${ }^{27-30}$ The enrich source of nutrients, minerals, and fibers of okra has invited to many pathogens, pests, and diseases infestation, ${ }^{31}$ and only the nematode pathogens causing root-knot, damage $10-40 \%$ of the total crop production annually, causing serious problems in 
our country and this indirectly affects our advanced agronomy-plantbreeding-horticulture-environment socio-economy green-sciencetechnology-communication-issues, and agricultural-economy also. Though the pesticides are very much effective. But it creates several problems in toxicity, pollution, cost-effectiveness, environmentfriendliness, and biodiversity conservation. ${ }^{3-20,27}$ On the other hand the pesticides block functional first known gene transfer between plants to insects or animals, which is used in the host's defenses mechanism for new pest-control strategies also, ${ }^{32}$ and recently in the 31 countries of the globe that higher airborne pollen concentrations correlated with increased SARS-CoV-2 infection rates. ${ }^{33}$
Recently after long lockdowns in Purba Bardhaman, West Bengal, India (Figure 1), only two day shows that the total COVID-19 positive cases are $3847-3849$, the total number of discharge cases are 3764-3769, the total number of COVID-19 death is 451-452, rate of recovery is $97.84 \%-97.92 \%$ and rate of mortality is $1.17 \%$ $1.17 \%$ respectively. So it is an urgent need to find out by developing policy-initiative, cheap, non-phytotoxic, and non-pollutant potentialhigh-diluted-biomedicines for preventing both the pandemic crisis by improving the agriculture system with the findings and other new research to develop future support and treatments.

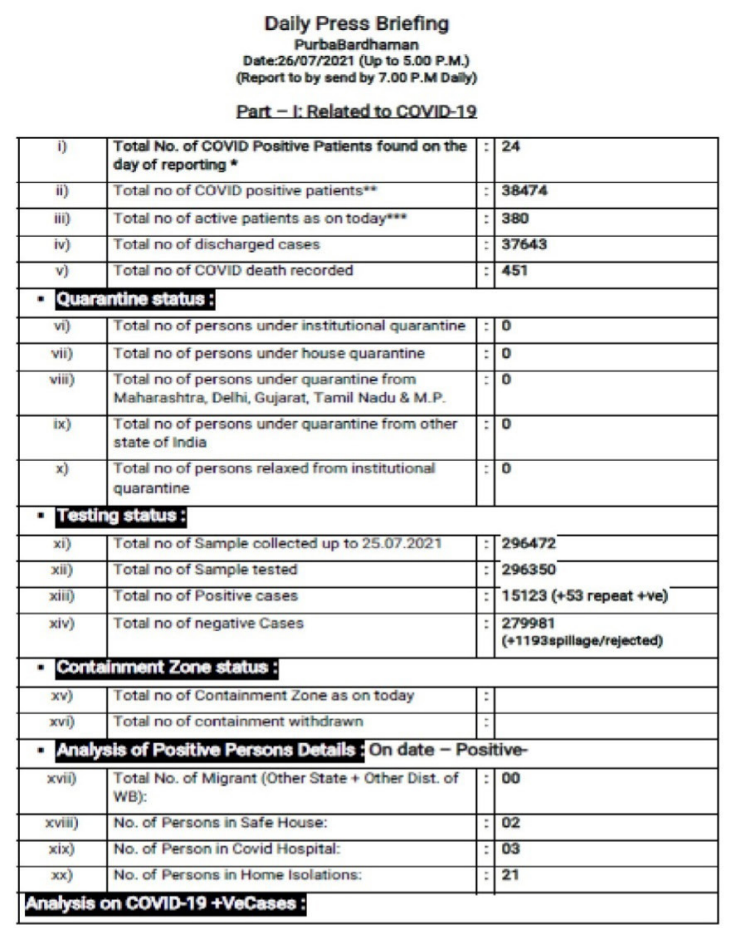

\begin{tabular}{|c|c|c|}
\hline$x \times(i)$ & Rate of Recovery" (Peroentage) & 97.84 \\
\hline xxii) & Rate of Mortalityty (Percentage) & 1.17 \\
\hline \multicolumn{3}{|c|}{ Report on Samplo Testing: } \\
\hline xx(iii) & Antigen Test & 820 \\
\hline$x \times(x)$ & RT.PCR Test & 565 \\
\hline xiv) & Test Result within $24 \mathrm{Hrs}$. & 901 (RAT-820+ RTPCAH-81) \\
\hline
\end{tabular}

Part-11:

Distribution of COVID Positive Cases found on 26/07/2021

\begin{tabular}{|c|c|c|c|c|c|c|c|c|c|}
\hline $\begin{array}{c}\text { Aushora } \\
m-1\end{array}$ & 0 & Galsi-1I & 0 & Ketugram-1 & 1 & Mongolkote & 0 & $\begin{array}{c}\text { Burdwan } \\
\text { Municipality }\end{array}$ & 5 \\
\hline $\begin{array}{c}\text { Aushgra } \\
m-\| 1\end{array}$ & 0 & Jamalpur & 3 & Ketugram-ll & 0 & Purbasthali-1 & 6 & $\begin{array}{c}\text { Dainhet } \\
\text { Municipality } \\
\end{array}$ & ${ }^{\circ}$ \\
\hline Bhatar & 0 & Kalna-1 & 2 & $\begin{array}{c}\text { Khandoghos } \\
\mathrm{h}\end{array}$ & 2 & Purbasthali-II & 1 & $\begin{array}{c}\text { Guskara } \\
\text { Municipality }\end{array}$ & o \\
\hline Burdwan-1 & 0 & Kalna-II & 0 & Manteswar & 0 & Raina-1 & 0 & $\begin{array}{c}\text { Kalina } \\
\text { Municipality }\end{array}$ & 0 \\
\hline $\begin{array}{c}\text { Burdwan- } \\
\text { II }\end{array}$ & 1 & Katwa-1 & 0 & Memari-1 & 0 & Raina-II & 0 & $\begin{array}{c}\text { Katwa } \\
\text { Municlpality }\end{array}$ & 0 \\
\hline Galsit- & 0 & Katwa-ll & o & Mernari-II & 1 & Other District & 1 & $\begin{array}{c}\text { Memari } \\
\text { Municipality }\end{array}$ & 1 \\
\hline
\end{tabular}

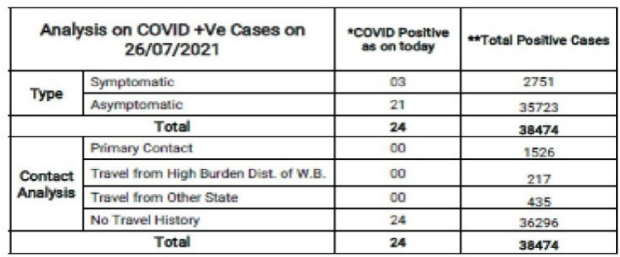

\begin{tabular}{|c|c|c|}
\hline & 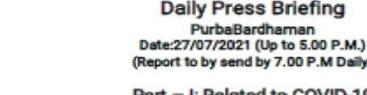 & \\
\hline & Part -1 : Related to COVID-15 & \\
\hline i) & \begin{tabular}{|l} 
Total No. of covil Positive Patients found on the \\
day of reporting"*
\end{tabular} & 25 \\
\hline ii) & Total no of Covid positive patients"t & 38499 \\
\hline iii) & Total no of active patients as on today"-" & 349 \\
\hline iv) & \begin{tabular}{|l|l|} 
Total no of dis charged cases \\
\end{tabular} & 37698 \\
\hline v) & Total no of COVID death recorded & 452 \\
\hline - Qua & intine status: & \\
\hline vi) & Total no of persons under institutional quarantine & 0 \\
\hline vii) & \begin{tabular}{|l} 
Total no of persons under house quarantine \\
\end{tabular} & 0 \\
\hline viii) & \begin{tabular}{|l} 
Total no of persons under quarantine fromm \\
Matharashitra, Delhi, Gujarat, Tamil Nadu \&.P.
\end{tabular} & 0 \\
\hline (ix) & $\begin{array}{l}\text { Total no of persons under quarantine from other } \\
\text { state of india }\end{array}$ & 0 \\
\hline (x) & $\begin{array}{l}\text { Total no of persons relaxed from institutional } \\
\text { quarantine }\end{array}$ & 0 \\
\hline - TeS & ta status: & \\
\hline$x \overline{x i}$ & Total no of Sample collected up to 26.07 .2021 & 297153 \\
\hline xii) & \begin{tabular}{|l|} 
Total no of Sample tested \\
\end{tabular} & 296641 \\
\hline xiii) & \begin{tabular}{|l|l} 
Total no of Positive cases \\
\end{tabular} & $15127(+53$ repeat +ve $)$ \\
\hline xiv) & \begin{tabular}{|l|l} 
Total no of negative Cases \\
\end{tabular} & $\begin{array}{l}280268 \\
\text { (t11938sillage/rejectede) }\end{array}$ \\
\hline$\cdot$ Con & inment Zone status: & \\
\hline$x \mathrm{xw}$ & Trotal no of Containment Zone as on today & \\
\hline$x$ xwi) & Total no of containment withdrawn & \\
\hline - Ana & Sis of Positive Persons Details: On date $-\mathrm{P}$ & \\
\hline xvii) & 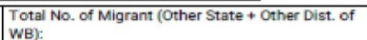 & 00 \\
\hline xviii) & No. of Persons in Safe House: & 02 \\
\hline$x(x)$ & No. of Person in Covid Hospital: & 02 \\
\hline$(x x)$ & No. of Persons in Home isolations: & 23 \\
\hline nalysit & on covid-19+VeCases: & \\
\hline
\end{tabular}

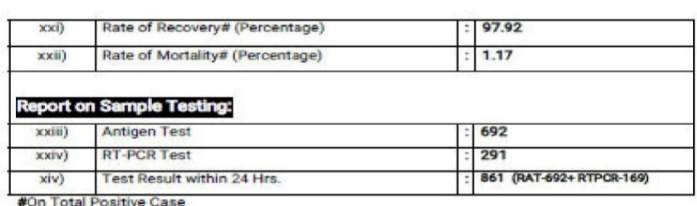

Part- II:

Distribution of COVID Pasitive Cases found on 27/07/2021

\begin{tabular}{|c|c|c|c|c|c|c|c|c|}
\hline $\begin{array}{l}\text { Aushgra } \\
m-1\end{array}$ & 0 & Galsi-II & 0 & Ketugram-I & 1 & $\underset{e}{\text { Mongolkot }}$ & 0 & $\begin{array}{c}\text { Burdwan } \\
\text { Municipalit } \\
y\end{array}$ \\
\hline $\begin{array}{c}\text { Aushgra } \\
\text { m-II }\end{array}$ & & Jarnalpur & 1 & Ketugram-ll & 1 & $\begin{array}{c}\text { Purbasthali } \\
-1\end{array}$ & 1 & $\begin{array}{c}\text { Dainh } \\
\text { Munici } \\
\text { y }\end{array}$ \\
\hline Bhatar & 0 & alna-1 & 4 & $\begin{array}{c}\text { Khando } \\
h\end{array}$ & 0 & $\begin{array}{c}\text { Purbasthali } \\
-\| 1\end{array}$ & 0 & $\begin{array}{l}\text { Gus } \\
\text { Muni }\end{array}$ \\
\hline Burdwan-1 & 1 & & & Manteswar & 0 & & 0 & \\
\hline $\begin{array}{c}\text { Burdwan- } \\
\text { II }\end{array}$ & 0 & Katwa-I & 0 & Mernari-1 & 5 & Raina-II & o & \begin{tabular}{|r} 
Kat \\
Munic \\
y
\end{tabular} \\
\hline alsi-1 & c & Katwa-II & 1 & & 0 & $\begin{array}{l}\text { Other } \\
\text { District }\end{array}$ & 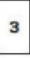 & \\
\hline
\end{tabular}

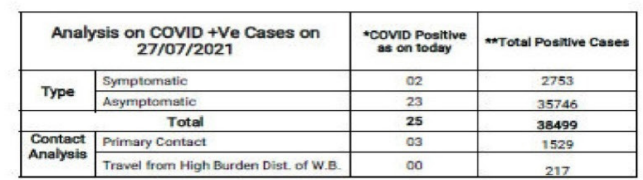

Figure I (Part-I\&II) Daily Press Briefing of the Purba Bardhaman District (Date:26\&27/07/202I, Upto5.00P.M. Daily).

Citation: Datta SC. Economic okra plant act as a preventive-COVID-19 vaccine advanced horticulture agriculture environment biodiversity conservation science technology communication applications issues. Hort Int J Med. 202 I;5(5):2II-220. DOI: I0.15406/hij.202I.05.0023। 
Work done: It is already shown that the various; pure compounds, homeopathy, allelopathy, plant extracts, phytomedicine, bio-agents, intercropped-/multi cropped-biomedicines, bio-medicinal-meals, biomedicine-vaccine, social-vaccine, policy-developed globalvaccine, many models, etc. are applied to regulate against different diseases causing pathogens, control the plants- and animal- diseases causing pathogen. ${ }^{3-20,27,34-63}$ But it's not achieving potential success all told the cases because of different causes.

It has also been observed recently that the animals- and plants biomedicines; Nematode Extract (NE) or nematode MT (NMT) and root galls (RG) extract or Gall MT is the safe alternative method to control root-knot diseases caused by nematode pathogens, by inducing their natural defense response of the host plants. ${ }^{15-20,35-37,39}$

Purpose: The main objectives of the work significance of the current study is to use the systematic signaling and induced natural defense or immunity in the host plants by applying ultra-high-diluted biomedicines; Gall 30C, Gall 200C, and Gall 100C, prepared from Gall MT (GMT) or gall roots (GR) as a preventive measure against root-knot, and COVID-19 diseases ideas, and also to find out and confirm the actual reasons of the genetic effects on the ultra-highdiluted-biomedicines for preventing diseases.

Summary of the paper: The current paper again contributes the development of the most policy-initiative, cheap, non-phytotoxic, nonpollutant, and side-effect free potential-high-diluted-biomedicines global vaccines; Gall 30C, Gall 200C, and Gall 1000C, for controlling both the pandemic crisis; root-knot diseases, and the future-pandemic COVID-19 like virus diseases, by enriching agriculture-environmenthealth-socio-economy-medical-pharmaceutical-science-technologycommunication-issues with the findings and other new research to drug development for the future support and the best treatments or potential preventive vaccine for all.

\section{Material and methods}

Location and preparation of high-diluted biomedicines Gall MT (GMT): The high-diluted biomedicines Gall MT (GMT), prepared from the root galls (RG) of okra plants which were collected from roots of the okra plants, Abelmoschus esculentus (L.) Moench Cv. Ankur-40, grown in the experimental garden of the Department of Zoology, VisvaBharati University, Santiniketan - 731235, and they were washed with sterile tap water, homogenizer and extracted with $90 \%$ ethanol at room temperature $\left(25 \pm 2^{\circ} \mathrm{C}\right)$ for 15 days and centrifuged at @3500 rpm for 5 minutes, and then the gall extract (GE) supernatant was collected and allowed to evaporate at room temperature $\left(25 \pm 2^{\circ} \mathrm{C}\right)$ and the biomedicines residues were kept over anhydrous calcium chloride $(\mathrm{CaCl} 2)$ for dehydration and stored at $4^{\circ} \mathrm{C}$. The crud GE- biomedicines residue was mixed with sterile distilled water just before application on the test plants. The crude residue was diluted in $90 \%$ ethanol at $1 \mathrm{mg} / \mathrm{ml}$ concentration and was prepared high-diluted biomedicines, Gall MT (Original Solution or Crude Extract i.e. Mother Tincture). ${ }^{4,7-9,11-20,34-42,47-49,53,54,58,61,63}$

Ultra-high-diluted biomedicines Gall 30, Gall 200C and Gall 1000C preparation: For the preparation of ultra-high-dilutedbiomedicines liquid drugs, the high-diluted GMT was diluted with $90 \%$ ethanol $(1: 100)$ proportionate in a round vial which was filled up to two-thirds of its space, tightly crocked, and the vials were given 10 powerful downward strokes of the arm for mechanical agitation (succession), forming the $1^{\text {st }}$ centesimal potency named Gall 1C. All the subsequent potencies were prepared by further diluting each potency with $90 \%$ ethanol in the same proportion (1:100) and the mixture was given 10 powerful downward strokes. In this way, different potencies of both the drugs; Gall 30C, Gall 200C, and Gall $1000 \mathrm{C}$, were prepared respectively. ${ }^{4,7-9,11-20,34-42,47-49,53,54,58,61,63}$

Ultra-high-diluted biomedicines Gall 30, Gall 200C, and Gall $1000 \mathrm{C}$ test solutions preparation: For the preparation of ultra-highdiluted test-solution of the biomedicines; Gall 30C, Gall 200C, and Gall 1000C, were diluted (v/v) @ 1ml drug/20ml sterile distilled water (in the proportion of drug: water $=1: 20$, containg $0.2 \mathrm{mg}$ drug) respectively, and the high-diluted-biomedicines liquid controlsolution of both the drugs were diluted (v/v)@1ml 90\% ethanol/20ml sterile distilled water (in the proportion of drug: water=1:20) respectively, and the control solution was prepared for comparison to the preparation of test solutions, and stored at $4^{\circ} \mathrm{C}$ for treatments media. ${ }^{4,7-9,11-20,34-42,47-49,53,54,58,61,63}$

Pot test and inoculation: Aseptically germinated seeds of Abelmoschus esculentus (L.) Moench Cv. Ankur-40 was sown at the rate of one seed/pot (32 cm diam.) containing a mixture of clay soil and composted manure $(2: 1 \mathrm{v} / \mathrm{v})$. The soil-filled pots were treated with boiling water 5 (five) times. The pots were divided into four batches/ groups; each numbering 10 :

I. uninoculated untreated,

II. inoculated untreated,

III. Gall 30C-pretreated inoculated, and

IV. Gall 200C-pretreated inoculated, and

V. Gall 1000C-pretreated inoculated. All the pretreatments were done by foliar spray. The experiment was conducted outdoors at an ambient atmospheric temperature $\left(27 \pm 2^{\circ} \mathrm{C}\right)$ and relative humidity $(75 \pm 5 \%)$. Plants were inoculated at the 12-leaf stage (Day-25) with M. incognita (J2) @ 3425 75 J2-larvae/pla nt. $4,7-9,11-20,34-42,47-49,53,54,58,61,63$

Treatments with ultra-high-diluted biomedicines Gall 30, Gall 200C, and Gall 1000C test solutions: The ultra-high-dilutedbiomedicines; Gall 30C, Gall 200C, and Gall 1000C -test solutions, were applied into the okra plants and sprayed on plants@20ml/ treated plants three days before inoculation for pretreatments with nematodes- $\mathrm{J}_{2}$ respectively. Control okra plants were treated with an equal amount $(20 \mathrm{ml})$ of control solutions prepared with sterile distilled water, and the plants were regularly watered in the morning and evening. During spraying, the soil surface underneath each plant was covered with a polythene sheet. Plants in both uninoculated untreated and inoculated untreated groups received a spray of an equal amount of control solutions. All treatments were done in hygienic conditions. ${ }^{4,7-9,11-20,34-42,47-49,53,54,58,61,63-65}$ All the data were analyzed by ANOVA (Analysis of Variance). The experiment was repeated thrice. Data from the last experiment are reported here.

Densitometerscanning of okra root (OR), okra root galls (ORG), and nematode -proteins: The okra root galls (ORG), OR, and nematode female (NF)-proteins separation was carried out by the method of Laemmli (1970) with the modifications as suggested by the LKB Instructional Manual (1986). A 10\% separating gel and 5\% stacking gel were used. The bands were scanned with a recording electrophoretic scanner (Biomidi, 96-300 densitometers). In Figure 2 and Table 2, the observation was recorded from the densitometer curve . $^{4,7,15-20,35,39,47-49,53,54,61,63,66}$ 

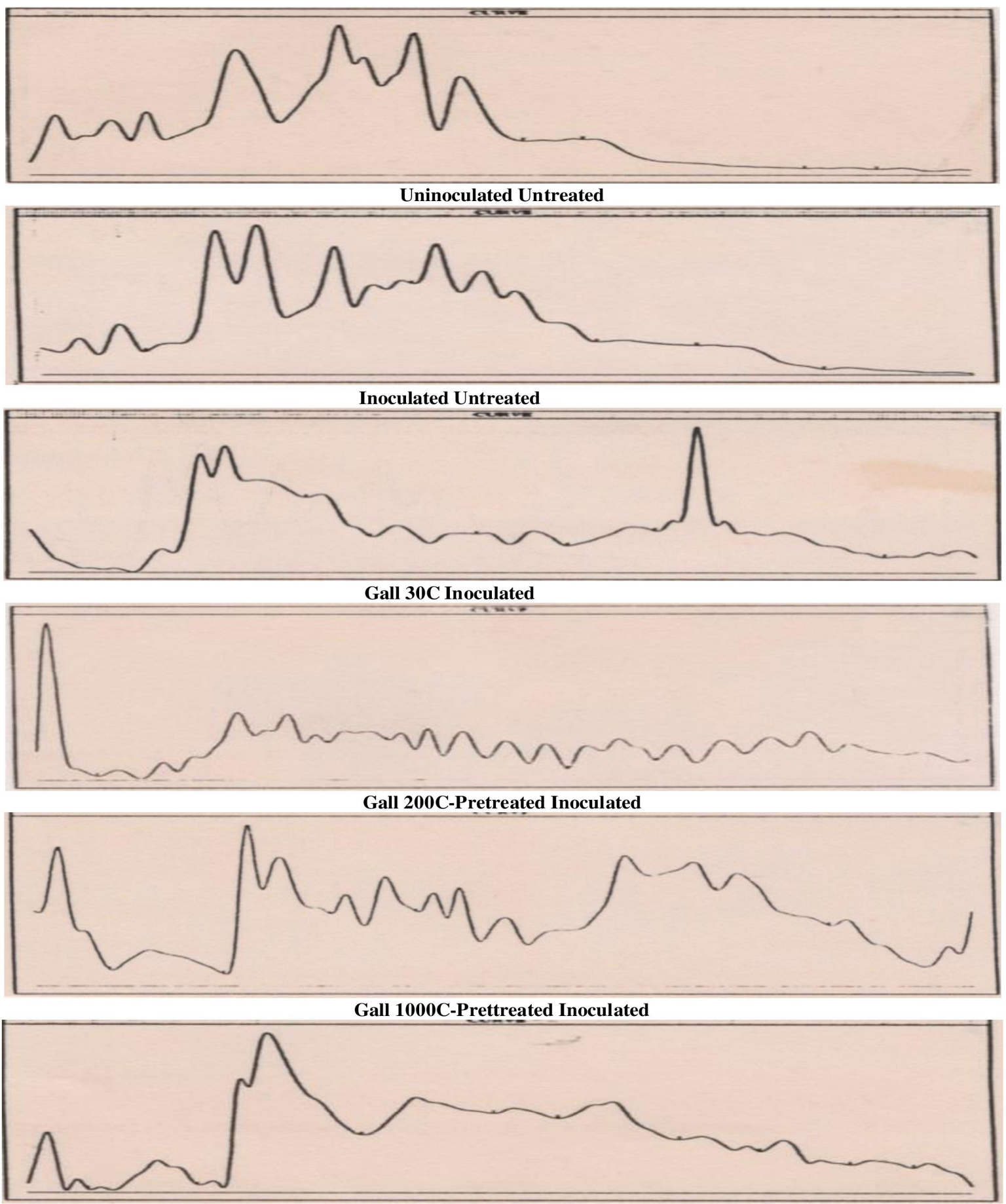

Nematode Female Proteins (NFP)

Figure 2 Densitometry tracings of root proteins of the Gall 30C, Gall $200 \mathrm{C}$ and Gall 1000C-treatedon okra with nematode proteins resolved on poly acrylamide gel electrophoresis (SDS-PAGE).

Toxicity: Biomedicines; Gall 30C, Gall 200C, and Gall 1000C, has exposed directly for the study of toxic effect on nematode juveniles after 2 hours exposure periods at room temperature $\left(20 \pm 2^{\circ} \mathrm{C}\right) ., 7,-9,11-$ $20,34-42,47-49,53,54,58,61,63$

Harvesting: All the okra plants were uprooted 53 days after the sowing of seeds. The following measure measurement was taken: biomass of shoot, root, and fruits, root gall number, nematode population in roots $(2 \mathrm{~g})$ and soil $(200 \mathrm{~g})$, the protein content of root and fruits. Proteins were estimated by the Folin-phenol method $[64,65]$. All the data were analyzed by analysis of variance (ANOVA). The experiment was repeated five times with similar results and the data from the third experiment were represented in Table 1. 
Table I Effect of the okra biomedicines Gall 30C, Gall 200C and Gall I000C-pretreatedon okraplants ${ }^{\mathrm{x}}$ inoculated with root knot nematodes

\begin{tabular}{|c|c|c|c|c|c|c|c|c|c|c|}
\hline \multirow[t]{2}{*}{ Treatments $^{Y}$} & \multicolumn{3}{|c|}{ Fresh Biomass $(\mathrm{g})^{\mathrm{x}}$} & \multirow[t]{2}{*}{$\begin{array}{l}\text { Number } \\
\text { of } \\
\text { Fruits }^{x}\end{array}$} & \multirow[t]{2}{*}{$\begin{array}{l}\text { Number } \\
\text { of Root } \\
\text { Galls }\end{array}$} & \multicolumn{2}{|c|}{$\begin{array}{l}\text { Nematode } \\
\text { Population } x\end{array}$} & \multicolumn{2}{|c|}{$\begin{array}{l}\text { Protein }{ }^{x} \text { Content } \\
(\%)\end{array}$} & \multirow[t]{2}{*}{$\begin{array}{l}\text { Number } \\
\text { of Total } \\
\text { Protein }\end{array}$} \\
\hline & Shoot & Root & Fruits & & & $\begin{array}{l}\text { Root } \\
(2 g)\end{array}$ & $\begin{array}{l}\text { Soil } \\
(200 \mathrm{~g})\end{array}$ & Root & Fruits & \\
\hline $\begin{array}{l}\text { I. Uninoculated } \\
\text { Untreated }\end{array}$ & $\begin{array}{l}196.28 \mathrm{aZ} \\
\pm 10.02\end{array}$ & $\begin{array}{l}26.58 c \\
\pm 1.22\end{array}$ & $\begin{array}{l}32.16 a \\
\pm 10.02\end{array}$ & $\begin{array}{l}22.12 b \\
\pm 1.02\end{array}$ & 0 & & & $\begin{array}{l}\mathrm{I} .24 \mathrm{~d} \\
\pm 0.22\end{array}$ & $\begin{array}{l}2.26 \mathrm{a} \\
\pm 0.02\end{array}$ & 11 \\
\hline $\begin{array}{l}\text { II. Inoculated } \\
\text { Untreated }\end{array}$ & $\begin{array}{l}75.01 \mathrm{c} \\
\pm 10.01\end{array}$ & $\begin{array}{l}68.49 a \\
\pm 6.01\end{array}$ & $\begin{array}{l}\text { I3.27c } \\
\pm 4.63\end{array}$ & $\begin{array}{l}07.3 \mathrm{lc} \\
\pm 2.0 \mathrm{l}\end{array}$ & $\begin{array}{l}424.13 a \\
\pm 87.11\end{array}$ & $\begin{array}{l}718 \mathrm{a} \\
\pm 22\end{array}$ & $\begin{array}{l}3 \mathrm{la} \\
\pm 43\end{array}$ & $\begin{array}{l}2.63 \mathrm{a} \\
\pm 0.01\end{array}$ & $\begin{array}{l}1.12 c \\
\pm 0.02\end{array}$ & 15 \\
\hline $\begin{array}{l}\text { III. Gall 30C- } \\
\text { Pretreated } \\
\text { Inoculated }\end{array}$ & $\begin{array}{l}184.04 b \\
\pm 1.02\end{array}$ & $\begin{array}{l}30.3 \mathrm{lb} \\
\pm 0.09\end{array}$ & $\begin{array}{l}35.99 c \\
\pm 0.01\end{array}$ & $\begin{array}{l}24 b \\
\pm 0.02\end{array}$ & $\begin{array}{l}69 b \\
\pm 1.11\end{array}$ & $\begin{array}{l}53 b \\
\pm 1.93\end{array}$ & $\begin{array}{l}54 b \\
\pm 2.02\end{array}$ & $\begin{array}{l}1.38 \mathrm{~b} \\
\pm 0.02\end{array}$ & $\begin{array}{l}1.92 c \\
\pm 0.02\end{array}$ & 19 \\
\hline $\begin{array}{l}\text { IV. Gall 200C- } \\
\text { Pretreated } \\
\text { Inoculated }\end{array}$ & $\begin{array}{l}194.92 \mathrm{a} \\
\pm 2.02\end{array}$ & $\begin{array}{l}27.10 c \\
\pm 1.02\end{array}$ & $\begin{array}{l}31.53 a \\
\pm 4.23\end{array}$ & $\begin{array}{l}25.68 \mathrm{a} \\
\pm 2.02\end{array}$ & $\begin{array}{l}\text { I3.07d } \\
\pm 2.31\end{array}$ & $\begin{array}{l}29 d \\
\pm 13\end{array}$ & $\begin{array}{l}48 c \\
\pm 24\end{array}$ & $\begin{array}{l}1.29 c \\
\pm 0.21\end{array}$ & $\begin{array}{l}2.19 b \\
\pm 0.03\end{array}$ & 23 \\
\hline $\begin{array}{l}\text { V. Gall I000C- } \\
\text { Pretreated } \\
\text { Inoculated }\end{array}$ & $\begin{array}{l}179.96 \mathrm{~b} \\
\pm 2.42\end{array}$ & $\begin{array}{l}29.22 b \\
\pm 2.04\end{array}$ & $\begin{array}{l}26.02 b \\
\pm 7.08\end{array}$ & $\begin{array}{l}24.24 b \\
\pm 1.04\end{array}$ & $\begin{array}{l}32.01 \mathrm{c} \\
\pm 1.03\end{array}$ & $\begin{array}{l}42 c \\
\pm 12\end{array}$ & $\begin{array}{l}46 c \\
\pm 24\end{array}$ & $\begin{array}{l}\mathrm{I} .37 \mathrm{~b} \\
\pm 0.1 \mathrm{I}\end{array}$ & $\begin{array}{l}1.97 \mathrm{~b} \\
\pm 0.03\end{array}$ & 16 \\
\hline
\end{tabular}

'x'-Mean of 10 replicates with S.E

'Y'-Okra plants inoculated at I2-leaf stage (Day-25) with M. incognita juveniles (3425 $\pm 75 \mathrm{~J} /$ /pot), pretreated with GMT at 8-leaf stage

(Day-22), and harvested 53 days after sowing ofgerminated seeds

' $\mathrm{z}$ '-Means carrying same letters in a column are not significantly different $(P \leq 0.05)$ by analysis of varience

In horticulture agriculture environment health-socio-economymedical-pharmaceutical science-technology communication applications: The different scientists, academicians, clinicians, scholars, researchers, students, farmers, administrators, institutions, communities, associations, teachers, staff, regulators, photographers, visitors, healthcare, media personnel, Burdwan Green Haunter and Students" Goal-NGO, and different club and social organizations, organize street cornering, workshops, seminars, agriculture fair, health camp, campaign, aware, make the news, and publish in different journals emphasis on "Prevent okra and COVID-19 diseases for the genetic basis of the ultra-high-diluted-biomedicines; Gall 30C, Gall 200C, and Gall 1000C advencing horticulture agricultureenvironment-health-socio-economy-medical-pharmaceuticalscience-technology-communication-application"\$3-20,34-63

\section{Results}

Effect on root-knot (RK) with ultra-high-diluted biomedicines Gall 30, Gall 200C, and Gall 1000C: The pretreated with ultrahigh-diluted-biomedicines; Gall 30, Gall 200C, and Gall 1000C significantly ( $\mathrm{P} \leq 0.05$ by ANOVA) increased plant growth in terms of the fresh biomass of shoot and fruits compared to the inoculated and untreated plants (Table 1). Root galls, nematode population in the root and soil, and root protein content were significantly $(\mathrm{P} \leq 0.05$ by ANOVA) reduced in pretreated plants as compared to the untreated ones (Table 1). The number of fruits and protein content in green fruit was significantly reduced in inoculated untreated plants as compared to the uninoculated ones, and all the pretreatments with biomedicines; Gall 30, Gall 200C, and Gall 1000C showed better plant growth and lesser intensity of the root-knot disease, and Gall 200C showed the best results in all respect (Table 1).
Effect on toxicity: The ultra-high-diluted-biomedicines biomedicines; Gall 30, Gall 200C, and Gall 1000C had not produced any direct toxic effect on nematode because no mortality occurs after 2 hours exposure period.

Genetic effects of okra root (OR), okra gall root (OGR) and nematodes female's proteins: Table 2 and Figure 2 ; shows the genetic effects on molecular weight $(\mathrm{kD})$ of okra root $(\mathrm{OR})$, and okra gall root (OGR) proteins for all pretreatments effects of ultra-high-diluted biomedicines; Gall 30, Gall 200C, and Gall 1000C on M. incognita pathogens causing RK-disease of the okra plants. An analysis of root proteins of all 5-groups and nematodesfemale's (NF) proteins by electrophoresis and densitometer scanning of all the test OR and OGR-proteins show that all the ultra-high-diluted biomedicines; Gall 30, Gall 200C, and Gall 1000C-pretreatments resulted in an increased number of proteins in the roots than uninoculated untreated and inoculated untreated groups; the highest number of root proteins in the ultra-high-diluted biomedicines Gall 200C-pretreated inoculated group is 23 , and next highest number of the root protein is 19 in the Gall 30C-pretreatment inoculated group, 16 in the Gall 1000C, and 15 in the inoculated untreated group and the lowest number of protein is 11 in the uninoculated untreated group respectively (Table 2 and Figure 2). The highest molecular weight of the OR-protein gene is $295 \mathrm{kD}$ and the lowest molecular weight of the OR-protein genes is $11 \mathrm{kD}$. The lowest number of the new pathogenesis-related protein genes (PR-proteins) is 4 in the uninoculated untreated okra roots, and the highest number of the new PR-proteins-genes is 22 in the high-diluted biomedicines- Gall 200C-pretreated okra-pretreatmentgroup, 18 in the Gall $30 \mathrm{C}$, and the same number i.e. 14 number of PR-proteins-genes is in both the ultra-high-diluted biomedicines Gall 1000C-pretreatment- and inoculated untreated -treatment-group respectively (Table 2 and Figure 2). 
And the NF contained 18-proteins-genes and the molecular weight of the NF proteins-genes ranging from the lowest $12 \mathrm{kD}$ to the highest $280 \mathrm{Kd}$, and the total number of the PR-proteins-genes of NF is 16 in comparison to the uninoculated untreated group (Table 2 and Figure 2).

\section{Discussion}

On growth: The present study clearly showed that the okra plants (OP)-growth in terms of fresh biomass of shoot and fruits, and the number of fruits was higher than inoculated untreated groups in all the pretreatment groups of OP treated with the ultra-high diluted biomedicines; Gall 30, Gall 200C, and Gall 1000C, but reverse in the fresh biomass of roots of inoculated untreated one. ${ }^{15-20,35-37,39}$

On root-knot (RK) diseases: All the pretreatment groups of Ops treated with ultra-high-diluted biomedicines; Gall 30, Gall 200C, and Gall 1000C, decreased RK-diseases in terms of nematode infection in root gall number, and nematode population in root in comparison to inoculated untreated groups, and the population of nematode in the rhizospheric soil was the maximum with the group treated with Gall 30, Gall 200C, and Gall 1000C-biomedicines, and minimum with the inoculated untreated group, due to potential ultra-high-diluted effects of biomedicines, and it is also showed that the biomedicines; Gall 30, Gall 200C, and Gall 1000C, might induce synthesis of some antagonistic substance in the treated-OP, which is proved from the inoculated untreated okra root galls (ORG) contained the highest protein-content due to presence of a large number of nematodes. ${ }^{3-20,34-63}$

On toxicity: In the recent study is also showed that the high-diluted biomedicines; Gall 30, Gall 200C, and Gall 1000C, had no direct toxic effects on nematodes juveniles, and okra plants, but it induced synthesis of some resistance substances in okra plants to $M$. incognita infection for preventing RK-diseases in the OP, and for these reasons, all the pretreated group had significantly greater fresh biomass of shoot-and fruits- plants than inoculated untreated one. ${ }^{15-20,35-37,39,67}$

On defense response: The present experiment showed that the high-diluted biomedicines; Gall 30, Gall 200C, and Gall 1000C, act as really effective preventive biomedicines natural vaccines against plant diseases because of their defense resistance, and it's known that the lectins accumulated in galled regions of the OR- infected with the RK-disease [68]. It's already known that many crop plants will be induced by acquiring systemic resistance for the localized virusinfection or non-pathogenic, and pathogenic-microorganisms or their culture-filtrates or gas or salicylic-acid, etc. protects plants from the numerous pathogens attack, by working systemically. ${ }^{15-20,35-37,39,67-79}$

On pathogenesis-related (PR) of root proteins-genes: It is known that the $M$. incognita is known to share common antigens with its host plants, ${ }^{80}$ and Iqbal et al. (2020) informed that the attempt to 'Silence Genes' of the root-knot nematode, $M$. incognita results in diverse responses including an increase and no change in expression of some genes. So in the all the treated plant's roots show that the ultra-high-diluted biomedicines; Gall 30, Gall 200C, and Gall $1000 \mathrm{C}$-pretreatments resulted in an increased number of proteins-genes in the root than inoculated untreated-okra plants-group; the highest number of PR-proteins-genes in the ultra-high-diluted biomedicines; Gall 30, Gall 200C, and Gall 1000C-pretreated group is 23, and the next highest number of the PR-protein-gene is 19 in the pretreatedGall 30C -inoculated group, 16 in the Gall $1000 \mathrm{C}$ group, and 15 in the inoculated untreated group, and the lowest number of protein is 11 in the uninoculated untreated group respectively, which proved and confirmed that during infection with the nematode, host plants showed minimal defense responses to the nematode because of this antigenic similarity, and the different PR-proteins-genes of the okra root gall (ORG) proteins ranging from $295 \mathrm{kD}$ (the highest molecular weight protein) to $11 \mathrm{kD}$ (the lowest molecular weight protein) of the OR-protein. And all the ultra-high-diluted pretreated biomedicines; Gall 30, Gall 200C, and Gall 1000C-stimulate the synthesis of the number of different PR-proteins-antigens-genes that must induce defense responses in which the nematodes fail to survive, and it is also proved from the plant-nematode interaction, newly synthesized PR-proteins genes have been found in potato plants infected with the potato-cyst-nematodes Globodera pallida and G. rostochiensis. ${ }^{82-84} \mathrm{It}$ is also reported that salicylic acid (SA) increases resistance in plants against RK-diseases by inducing expression and accumulation of pathogenesis-related-I protein $(14 \mathrm{kD}, \mathrm{PR}-\mathrm{I})$ in the sprayed plant-root and leaves, and it sprays enhances-PAL higher activity in infected-ro ots. ${ }^{15-20,35-37,39,67,77-79,81}$

On pathogenesis-related (PR)-proteins-genes of NF: The sixteen PR-proteins-genes out of total eighteen proteins-genes of NF of $M$. incognita in comparison to the uninoculated untreated group, and the molecular weight of the nematode-proteins-genes ranging from $12 \mathrm{kD}$ to $280 \mathrm{kD}$, already confirmed the potential efficacy of the highdiluted biomedicines-Gall MT or GMT use as an effective stimulus for the expression of these various new 16 defense-related PRproteins-genes might be provided resistance to nematode-infection in okra plants due to nematodes present in the gall roots also, and it can be preventing pathogenesis in patients with COVID-19 due to more or less proteins-genes range $(240 \mathrm{kD}$ to $26 \mathrm{kD})$ in different bovine- and human- coronavirus-structural-proteins which send genetic-information, and the SARS-CoV-2 genes may integrate with human-DNA to code the essential nonstructural-proteins like an RNA-polymerase also, and the nematode-proteins-genes slip into human-chromosomes and the diverse immunologicalfactors on viral-dissemination, immunotherapeutic-options, and inflammatory-responses, and need molecular-characterization and understanding of the human-coronavirus-life-cycle, structural and functional properties of SARS-CoV-2 spike-protein for potential antivirus-drug development, and analysis of therapeutic-targets for SARS-CoV-2 and discovery of potential-drugs by computationalmethods, and genomic-characterization and epidemiology of 2019 or genomic-epidemiology has come of age during this pandemic affording to track SARS-CoV-2 sequences helped identify worryingvariants, with implications for virus-origins and receptor-binding also, for preventing the COVID-19,- but researchers are blind to emerging-mutations in some-regions, and so it is thought, "the next pandemic by transforming food-systems for affordable healthy-die ts". ${ }^{15-20,35-37,39,67,79,85-88}$ Recently it may help from the report that cellular senescence $(\mathrm{SnC})$ contributes to inflammation, multiple-chronicdiseases, and age-related dysfunction, and the $\mathrm{SnC}$ become hyperinflammatory in response to pathogen-associated-molecular-patterns (PAMPs), including SARS-CoV-2 Spike-protein-1, increasing expression of viral entry proteins and reducing anti-viral geneexpression in non-SnCs through a paracrine-mechanism. ${ }^{89}$

On genetic effects of okra root galls-pathogenesis-related (PR)proteins-genes: In the ultra-high-diluted biomedicines-Gall 200C -pretreated okra root galls (ORG), the 22 PR-proteins-genes out of total 23 proteins-genes in comparison to the uninoculated untreated okra plant group, and the molecular weight of the ORGs-proteinsgenes ranging from lowest $12.5 \mathrm{kD}$ to highest $295 \mathrm{kD}$, proved the potential efficacy of the pretreatment- ultra-high-diluted biomedicinesGall 200C act as the most effective stimulus for the expression of these many new 22 defense-related PR-proteins-genes which might 
be provided resistance to nematode-infection in okra plant. All the ultra-high-diluted biomedicines; Gall 30, Gall 200C, and Gall $1000 \mathrm{C}$-pretreatments collectively resulted in an increased number of PR-proteins-genes. And the genetic effects of ultra-high-diluted biomedicines; Gall 30, Gall 200C, and Gall 1000C-pretreatments resulted in an increased number of proteins-genes, are thought to induce systemic acquired resistance response of all the pretreated plants through the expression of pathogenesis-related (PR)proteins-genes (22 to 14 numbers), which are more or less similar molecular range $(295 \mathrm{kD}$ to $11 \mathrm{kD})$ of various coronavirus, and it will responsible for preventing RK and COVID-19 like virus diseases by inducing resistance of plants or increasing immunity of animals respectively, and advanced horticulture agriculture environment health socio-economy medical-pharmaceutical science-technologycommunication-application issues. ${ }^{15-20,35-37,39,67,79,85-89}$

Future suggestions: The okra ultra-high-diluted biomedicines; Gall30C, Gall 200C, and Gall 1000C-pretreated okra root galls (ORG) protein could be induced the production of new defense-related PRgenes in the test plants and might be confirmed, and in near future, synthetic production of the RG-proteins would be the most potential cost-effective personalized-biomedicine OR social vaccine OR vaccine against coronavirus-2 like pandemic diseases by increasing immunity, and helping policy initiative clinical research in all areas in the field of advanced agronomy-plant-breeding-horticultureagricultural, aquatic sciences, environment, socio-economy, and green-science-technology-communication issues by preventing okra root-knot and COVID-19 also. Thus, RG-proteins will serve as very effective biomedicines that would be the most effective cheapest, nonphytotoxic, non-pollutant, conserve our biodiversity, and this vaccine might be the most effective against the delta variant of coronavirus, and scholars that give good scope for new development and future research in various fields of pathology-medical-pharmacology preventing fungal infections by increasing the post-COVID weakened lungs as well as the immune also. ${ }^{15-20,35-37,39,67,90-91}$ And in the near future ultra-high-diluted biomedicines; Gall30C, Gall 200C, and Gall $1000 \mathrm{C}$ pretreatment gall root (GR) may be used as mixing vaccines to provoke potent immune responses for the real-world efficacy and rare side effects. ${ }^{92}$ And the Coronavirus $3^{\prime}-5^{\prime}$ exoribonuclease $($ ExoN), substrate specificity and give insight into the molecular mechanisms of mismatch correction during coronavirus RNA synthesis, provide guidance for the rational design of improved anticoronavirus therapies, for the future mitigation strategies, and Covid appropriate and risk behavior at slums different areas also. ${ }^{93-95}$ It is the most economical plant for the allround benefitted by all and provide also the whole plant act as 'Nature's-Gift Preventive-COVID-19 Vaccine for All'. It also control future 'X-diseases ${ }^{96-104}$ for the 'Few suggestions were made for consideration' due to its cost-effectiveness, eco-friendliness, easily-manufacturability, easily-applicability, easilyavailability, and side-effects-freeness, etc.

\section{Conclusion}

The economic plants, okra, the 'Nature's-Gift to Human-DiseaseFree-Healthy-Life', and the ultra-high-diluted okra biomedicines, prepared from okra root, the Gall 30C, Gall 200C, and Gall 1000C are highly potent against the diseases, with increasing plant growth and fruit production. The ultra-high-diluted-biomedicines Gall 200C confirms the most potential result in all respects. The genetic-effects of ultra-high-diluted-biomedicines thought to induce systemic acquired resistance response of the treated plants through the expression of pathogenesis-related (PR)-proteins-genes (22 to 4 numbers), which are more or less similar molecular range $(295 \mathrm{kD}$ to $11 \mathrm{kD})$ of many coronaviruses, and it will be responsible for preventing plant and
COVID-19 like variant-virus diseases by inducing defense-resistance or increasing innate-immunity, and advening horticulture, greenagriculture, environment, global health, socio-economy, medical, pharmaceutical-science, technology, communication- application issues with the toxic-free world, and it may help to develop best potential new preventive treatments methods or drug or vaccines, in the field of '21st Century COVID-19 like a pandemic in the new normal situation in future. And in the near future pretreatment of gall root may be used as mixing vaccines to provoke potent immune responses for the real-world efficacy and rare side effects, with the allround development and benefitted by all and provide the whole plant act as 'Nature's-Gift Preventive-COVID-19 Vaccine for All also'.

\section{Acknowledgments}

I am grateful to Ex-Prof. Dr. N. C. Sukul and Prof. Dr. S. P. Sinhababu, for necessary guidance and all facilities for the research work in the Parasitology-Laboratory, Department of Zoology, VisvaBharati, Santiniketan - 731235, West Bengal, India. I am also thankful to Dr. Tapan Mondal for statistical analysis, and Mrs.Rupa Datta, Ex-Prof. Shelley Bhattacharya, and Dr. Partha Roy for biochemicalwork and densitometer-scanning of the same Department. I am also thankful to Prof. Dr. N. Banerjee and Dr. K. Ghosh, PlantBiotechnology-Laboratory, Department of Botany, Visva-Bharati, for needful bits of help. I express my deep gratitude to Mr. Rakesh Khan, Secretary, and Mr. Subhendu Bose, President with all Young-GreenMembers of the "International-NGO named Burdwan-Green-Haunter and Students'-Goal" for arranging to many awareness programs on COVID-19. Last but not the least; I am thankful to the eminenteducationist-philosopher-social-worker Sri Tapaprakash Bhattacharya for inspiration and guidance.

\section{Conflicts of interest}

The author declares that there is no conflict of interest exists.

\section{References}

1. Souilmi Y, Lauterbur ME, Tobler R, et al. An ancient viral epidemic involving host coronavirus interacting genes more than 20,000 years ago in East Asia Cur Biol. 2021;31:1-11.e1-e9.

2. Dance A. Beyond coronavirus: the virus discoveries transforming biology. Nat. 2021;595:22-25.

3. Datta SC. Weed-Plant Act as Vaccine against Plant-and-COVID-19 Diseases: Enriched-Agriculture-Health-Development Socio-Economy Sciences-Technology-Communication-Application. Int J Pharma Sci Clinic Res. 2021;1(1):1-17.

4. Datta SC. Immediate apply cost-effective easily preparable-available $21^{\text {st }}$ century potential -ayurvedic-herbal-integrative-medicine-vaccine of COVID-19: achieved agriculture healthcare-socio-economy science technology communication mechanism. Int $J$ Res-Granthaalayah. 2021;9(1):227-247.

5. Datta SC. Only Environmental Science Act as Natural Bio-medicine Preventive Epidemic Model of 21st Century Pandemic Diseases. Environ Sci Ind J. 2021;17(1):e177.

6. Datta SC. Students Act as 21st Century Preventive-Pandemic-COVID-19 Model: Improved Advance-Clinical-Toxicology Biomedicine GreenSocio-Economy Science-Technology-Innovations. $\mathrm{Adv} \mathrm{Cl}$ Toxicol. 2021d;6(1):000204.

7. Datta SC. Immediate apply cost-effective easily preparable-available $21^{\text {st }}$ century potential -ayurvedic-herbal-integrative-medicine-vaccine of COVID-19: achieved agriculture healthcare-socio-economy science technology communication mechanism. International Journal of Research-Granthaalayah. 2021e;9(1):227-247. 
8. Datta SC. High-Diluted Pharmacological-Potential Biomedicines Prevent 21st Century COVID-19 Like Pandemic: Improved DrugsResearch Biodiversity Agriculture Socio-Economy. Edit Am J Phar. 2021;4(1):1031.

9. Datta SC. Amaranth Plant Protects Climate-Health-Development SocioEconomy Sciences-Technology-Communication: Act as Potential Biomedicine-Vaccine against Plant and 21st Century-Epidemic COVID-19 Diseases. Exp Opin Env Biol. 2021;10:1

10. Datta SC. $21^{\text {st }}$-Century Preventive Non-Medicinal-COVID-19-StudentsModel: Improved Med Life Clinics Sciences Technology Communication. Med Life Clin. 2021;3(1):1029.

11. Datta SC. Dinna Nath Das-Middle English School and -Dispensary Act As a Model: The 21st-Century-Coronavirus-2 Resistance-FuturisticCommon-Ecofriendly-Complex-Green-Digital-School-HealthEcosystem by Bio-Medicine-Vaccine-Nationalism-Equity-Passport. SunText Rev Arts Social Sci. 2021; 2(1):117-224.

12. Datta SC. Sustainable Reopening of School Preventing ReinfectionCoronavirus 2 in New-Normal by Vaccine-Nationalism-Equity-Passport with Ginger-Drinks-Bio-Medicinal-Mid-Day-Meals! Int $J$ ResGranthaalayah. 2021;9(5):165-170.

13. Datta SC. Emergency Application of Ultra-High-Diluted-Biomedicines as Vaccine-Nationalism-Equity-Passport Preventing-Coronavirus-2: Developed Medical Health Clinical ResearchScience Technology Communication. Medico Res Chron 2021;8(2):132-135.

14. Datta SC. Vaccine-Passport Bio-Medicinal-Meals Prevent ReinfectionCoronavirus-2: Improved Global-Health-Clinical-Drug-DiscoveryEducation-Research Socio-Economy-Science-TechnologyCommunication-Application. Aditum J Cli Biomed Res. 2021;2(3):1-7.

15. Datta SC. Nematode Extract and Acaciasides Use as Preventive Biomedicines Against Plant Diseases: Improved Earth-EnvironmentalHealth-Research Science-Technology-Communication and May be Controlled $21^{\text {st }}$-Century Pandemic Diseases. Eart \& Envi Scie Res Rev. 2021;4:55-60.

16. Datta SC. Animal-Biomedicine Controls Root-Knot-Disease in LentilCallus-Culture: Enriched Advanced-Clinical-Toxicology Socio-Economy Science-Technology-Communication by Preventing $21^{\text {st }}$-CenturyCOVID-19-Like-Pandemic-Diseases. Adv Cli Toxicol. 2021;6(2):000214.

17. Datta SC. Biomedicines Suppress Root-knot Disease of Tomato and Coronavirus-Like-Pandemic-Diseases: Improved Agriculture GreenSocio-Economy Aquatic-Science-Technology-Communication. J Agric Aqua Sci. 2021;1:08-10.

18. Datta SC. Genetic Basis of Nematode Extract May Be PreventiveBiomedicines Against Coronovirus-2 by Controlling Root-Knot-Disease of Cowpea-Root-Callus: Enriched Agriculture Clinical Medical-ScienceTechnology-Communication. Glob J Cl Med C Rep. 2021p;1(1):010-018.

19. Datta SC. Artemisia nilagirica will Be the Best Vaccine against Okra and COVID-19: Enriched Agriculture Medical-Science TechnologyMechanism Applications. IASR Journal of Medical and Pharmaceutical Science(IJMPS). 2021;1(2):26-43.

20. Datta SC. Genetic effects of the biomedicines Gall MT (GMT) on advanced agronomy-plant-breeding-horticulture-environment socioeconomy green-science-technology-communication-issues by preventing okra root-knot and COVID-19. Advances in Agronomy Plant Breeding and Horticulture. 2021.

21. Phillips S, Williams MA. Confronting Our Next National Health Disaster — Long-Haul Covid. N Eng J. 2021;1-3.

22. Hakmaoui A, Khan F, Liacini A, et al. Relevant SARS-CoV-2 Genome Variation through Six Months of Worldwide Monitoring. Hindawi Bio Med Res Int. 2021;5553173:10.

23. Workie E, Mackolil J, Nyika J, et al. Deciphering the impact of COVID-19 pandemic on food security, agriculture, and livelihoods: A review of the evidence from developing countries. $\mathrm{Cu}$ Res Environ Sustain. 2020;2:100014
24. World Bank. Food Security and COVID-19. 2021

25. Kochlar SI. Okra (lady finger) in tropical crops. A text book of economic botany. 1986;263-264.

26. Chowdhury S, Kumar S. Okra Breeding: Recent Approaches and Constraints. Anna Biol. 2019;35(1):55-60.

27. Datta SC. Okra Maybe Potential Cost-Effective PersonalizedBiomedicines Social-Vaccine against COVID-19: Improved Immunity Food-Security Green-Economy Science-and-Technology-Communication Applications. Innov J Med Sci. 2020;4(2):5-20.

28. Gemede HF, Ratta N, Haki GD, et al. Nutritional Quality and Health Benefits of Okra (Abelmoschus esculentus): A Rev J Food Pro Technol. 2015;6:458

29. Sindhu RK, Puri V. Phytochemical, Nutritional and Pharmacological evidences for Abelmoschus esculentus (L.). J. Phytopharmacol. 2016;5(6):238-241.

30. Anonymous. Indian Horticulture Database. National Horticulture Board Ministry of Agriculture, Gov. India, Gurgaon. 2015.

31. Chowdhury S, Kumar S. Okra Breeding: Recent Approaches and Constraints. Anna. Biol. 2019;35(1):55-60.

32. Ledford H. First known gene transfer from plant to insect identified. Nat Ne. 2021

33. Damialis A, Gilles S, Sofiev M, et al. Higher airborne pollen concentrations correlated with increased SARS-CoV-2 infection rates, as evidenced from 31 countries across the globe. PNAS. 2021;118(12): e2019034118.

34. Datta SC, Mukherjee R. High-Diluted-Potential-Internal-Biomedicines Zingiber officinale Extract Prevent 21st-Century Pandemic: Enriched Drugs Health Socio-Economy. Unit J Inter Med. 2021;V1(3):1-4.

35. Datta SC, Datta R. Defence resistance of okra against root-knot disease by bio-nematicides. Pro Zool Soc Cal Univ WB Ind. 2000;59(2):75-82.

36. Datta SC, Sinhababu SP, Banerjee N, et al. Meloidogyne incognita extract reduces M. incognita infestation of tomato. Ind J Nematol 1998;28(1):1-5.

37. Datta SC, Datta R., Sinhababu SP, et al. Acaciasides and root-knot nematode extract suppress Meloidogyne incognita infection in lady's finger plants. Proceeding of National Seminar on Environmental Biology, Visva-Bharati, Santiniketan, West Bengal, India. 1998;205-209.

38. Datta SC, Sinhababu SP, Sukul NC. Improved growth of silkworms from effective treatment of mulberry diseases by Accacia auriculiformis extract. Sericol. 1997;37(4):707-712.

39. Datta SC. Bio-nematicides in the control of root-knot nematode. Ph.D. thesis, Department of Zoology, VisvaBharati, Santiniketan-731235, West Bengal, India. 1999

40. Datta SC. Effects of Cinaon root-knot disease of mulberry. Homeopath 2006;95:98-102.

41. Datta SC. Possible use of amaranth as catch crop for root-knot nematodes intercropped with okra. Phytomorphol. 2006;56:113-116.

42. Datta SC. Enriched Sericulture from Effective Treatment of Mulberry Diseases by Homeopathic Medicines. Adv Biochem Biotechnol. 2019;7:084.

43. Datta SC. Improved Environment by Identification of More Susceptible Plant Between Cowpea and Mulberry for Root-Knot Disease. Op Acc J Environ Soil Sci. 2019;2(5):242-245.

44. Datta SC. Enriched School Health For The Effective Healthcare BioActivity of Barn Owls. Res Rev Heal Car Op Acc J. 2019;3(3):269-275.

45. Datta SC. Enriched School Environment for the Effective Bio-Activity of Barn Owls. Int j Hor Agric Food scie. 2019;3(3):119-126.

46. Datta SC. Enriched Science and Technology Communication Economy in Agriculture by Use of Acacia sides as Potential Bio-Agents against Various Pathogens. Adv Agric Hort Entomol. 2020;2:1-13. 
47. Datta SC. Acacia auriculiformis-Extract Synthesis PR-Proteins Developed Potential Biomedicines-Vaccine against Okra-Diseases and COVID-19: Improved Science Technology Communications BioEconomy Applications. Int J Res.-Granthaalayah, 2020;8(10):249-270.

48. Datta SC. Cina-Pretreatments Act as Potential-Biomedicine-Vaccine against COVID-19 and Okra-Plant-Diseases: Synthesis PR-Proteins Increased-Immunity Improved Biomedicines-Economy Applications Science-Technology-Communications. Int J Ayur. 2020;5(12):05-26.

49. Datta SC. Okra Maybe Potential Cost-Effective PersonalizedBiomedicines Social-Vaccine against COVID-19: Improved Immunity Food-Security Green-Economy Science-and-Technology-Communication Applications. Innovat J Med Sci. 2020;4(2):5-20.

50. Datta SC. Intercropped Cowpea Maybe Use as Biomedicine Improved Immunity against COVID-19: Enriching Science and Technology Communication Applications Food Security Economy. Diag Therap Comple Tr Med. 2020;2020(1):35-48

51. Datta SC. Weeds-Vegetables and Fruits Act as Potential Biomedicines against COVID-19: Enriched Agriculture Biodiversity Socio-Economy Science Technology Communications by Controlling Plants Diseases. $J$ Exp Biol Agric Sci. 2020;8:S139-S157.

52. Datta SC. Biomedicines-Aakashmini Cost-Effective COVID-19 vaccine: Reduced Plant-Diseases Enriched Science Technology Communications Socio-Economy Bio-Applications. Global J Biosci Biotechnol. 2020;9(4):127-144

53. Datta SC. Discovery of COVID-19 Vaccine by Using Acaciades as a Phytomedicine Improving Science and Technology Communication Applications- An Ideas. Open Acc J Biogeneric Sci Res. 2020;2(1):1-30.

54. Datta SC. Improved Science and Technology Communications: Barn Owl Act As Social Vaccine Against COVID-19. Int J Lat Res Sci Technol. 2020;9(3):6-13.

55. Datta SC. Potential Policy-Developed Global-COVID-19-Vaccine: Enriched Medical Sciences and Technology Green-Socio-Economy. Cross Cur Int J Med Biosci. 2020;2(10):143-154.

56. Datta SC. Improved midday meal by using cowpea as eco-friendly crop controlling root-knot forming global, green, growth and green economy Int J Adv Res 2020.

57. Datta SC. Biomedicines-Cina against COVID-19: Controlled Plan Diseases Enriched Science and Technology Communication Green Economy. The Int J Res -Granthaalayah. 2020;8(9):234-255.

58. Datta SC. NGO Act as Potential-Policy-Developer Social-VaccineCOVID-19 Epidemic-Model until Discovery-of-Medical-Vaccine: Achieved Green-Socio-Economic Welfare Science Technology Innovations. Arch Commun Med Pub Heal. 2020;6(2):225-232.

59. Datta SC. Biological and BioSystems Engineering Barn Owl Controlled COVID-19: Engineering Bio-mechanical Biomedical Science Technology Communication Enriched Agriculture Environment. Int J Engineer Sci Inv. 2020;2319-6734.

60. Datta SC. Cina-Pretreatments Act as Potential-Biomedicine-Vaccine against COVID-19 and Okra-Plant-Diseases: Synthesis PR-Proteins Increased-Immunity Improved Biomedicines-Economy Applications Science-Technology-Communications. Int J Ayurv. 2020;5(12):05-26.

61. Datta SC. Artificial-Nest Rainwater-Harvesting with Fishery and Floatingor-Rooftop-Gardening Act as $21^{\text {st }}$ Century Civil-Engineering COVID-19 Epidemic-Model: Improved Biodiversity Agriculture Socio-Economic Environmental-Sciences Technology-Communication. J Civil Engine Environ Sci. 2020;6(2):022-036.

62. Datta SC. Homeopathic Medicines Aakashmoni Will Be the Best Vaccine Against COVID-19: Enriching Agriculture Science and Technology Communication Mechanism Application Issues. Int J Res GRANTHAALAYAH. 2020;8(11):333-361
63. Lowry OH, Rosebrough NJ, Farr AL, et al. Protein measurement with Folin-phenol reagent. J Biol Chem.1951;193:265-275.

64. Chatterjee A, Sukul NC. Total protein of galled roots as an index of root-knot nematode infestation of lady finger plants. Phytopathol. 1981;71:372-274.

65. Laemmli UK. Cleavage of structural protein during the assembly of the head of bacteriophage T4. Nat. 1970;227:680-685

66. Datta SC. Animal-Biomedicines Prevent Disease of Tomato and Coronavirus-Like-Pandemic-Diseases: Enriched Agriculture SocioEconomy Science-Technology-Communication-Issues! Merit Res J Microbiol Biol Sci. 2021;9(3):1-4.

67. Das S, Sukul NC, Mitra D, et al. Distribution of lectin in nematode infested and uninfested roots of Hibiscus esculentus. Nematol Medit. $1989 ; 17: 123-125$

68. Ross AF. Systemic acquired resistance induced by localized virus infection in plants. Virol. 1961;14:340-358.

69. Descalzo RC, Rahe JE, Mauza B. Comparative efficacy of induced resistance for selected diseases of greenhouse cucumber. Can J Pl. Path. 1990; $12: 16-24$

70. Kuc J, Strobel NE. Induced resistance using pathogens and nonpathogens In: Biological Control of plant Diseases, (Eds. E.C. Tjamos) Plenum Press, New York, 1992:295-300.

71. Merra MS, Shivanna MB, Kageyma K, et al. Plant growth promoting fungi from Zoysia grass rhizosphere as potential inducers of systemic resistance in cucumbers. Phytopathol.1994;84:1399-1406.

72. Kiessig DF, Malamy J. The salicylic acid signal in plants. Pl Mol Biol. 1994;26:1439-1458.

73. Kiessig DF, Durner J, Noad R, et al. Nitric oxide and salicylic acid signaling in plant defense. Proc Nat Aca Sci. 2000;97:8849-8855.

74. Schneider M, Schweizer P, Meuwly P, et al. Systemic acquired resistance in plants. Int J Cytol. 1996;168:303-340.

75. Mauch Mani B, Metraux JP. Salicylic acid and systemic acquired resistance to pathogen attack. Ann Bot.1998;82:535-540.

76. Nandi B, Sukul NC, Banerjee N, et al. Salicylic acid enhances resistance in cowpea against Meloidogyne incognita. Phytopathol Med. 2002;41:39 44

77. Nandi B, Kundu K, Banerjee N, et al. Salicylic acid-induced suppression of Meloidogyne incognita infestation of okra and cowpea. Nematol. 2003;5(5):747-752.

78. Mukherjee A, Mondal P, Sinhababu SP. Nematode extract-induced resistance in tomato against Meloidogyne incognita. Indian J Sci Technol. 2020;13(14):1476-1479.

79. McClure, Michael A, Misaghi I, et al. Shared antigens of parasitic nematodes and host plant. Nat. 1973;244-306.

80. Iqbal S, Fosu Nyarko J, Jones MGK. Attempt to Silence Genes of the RNAi Pathways of the Root-Knot Nematode, Meloidogyne incognita Results in Diverse Responses Including Increase and No Change in Expression of Some Genes. Front Pl Sci. 2020;11(328):1-13.

81. Hammond Kosack KE, Atkinson HJ, Bowles DJ. Systemic accumulation of novel proteins in the apoplast of the leaves of potato plants following root invasion by the cyst-nematode Globodera rostochiensis. Physiol Mol Pl Pathol. 1989;35:495-506.

82. Rahimi S, Perry RN, Wright DJ. Induction and detection of pathogenesisrelated proteins in leaves and roots of potato plants infected with pathotypes of Globodera pallida. Fund. Appl Nematol. 1993;16:549-556.

83. Rahimi S, Perry RN, Wright DJ. Identification of pathogenesis-related proteins induced in leaves of potato plants infected with potato cyst nematodes, Globodera species. Physiol Mol Pl Pathol. 1996;49:49-59. 
84. Rabaan AA, Al Ahmed SH, Garout MA, et al. Diverse Immunological Factors Influencing Pathogenesis in Patients with COVID-19: A Review on Viral Dissemination, Immunotherapeutic Options to Counter Cytokine Storm and Inflammatory Responses. Pathogen. 2021;10:565.

85. Cohen J. For WHO leader, a 'feeling that we're failing'. Sci. 2021;372(6549):1376-1377.

86. Cohen J. Do coronavirus genes slip into human chromosomes? Sci 2021;372(6543):674-675

87. Cohen J. Further evidence supports controversial claim that SARS-CoV-2 genes can integrate with human DNA. Sci. 2021;

88. Camell CD, Yousefzadeh MJ, Zhu V, et al. Senolytics reduce coronavirusrelated mortality in old mice. Sci. 2021; eabe4832:1-20.

89. Martin YH. COVID-19: Which vaccines are effective against the delta variant? 2021.

90. Hakmaoui A, Khan F, Liacini A, et al. Relevant SARS-CoV-2 Genome Variation through Six Months of Worldwide Monitoring. Hindawi BioMed Res Int. 2021:5553173:10.

91. Grover N. Covid 'perfect storm' as more patients hit by fungal infections The Guardian. 2021.

92. Lewis D.Mix-and-match COVID vaccines: the case is growing, but questions remain. Nat. 2021.

93. Kar S, Mohapatra I, Mishra A, et al. Mitigation strategies and Covid appropriate and risk behavior : A descriptive study at slums of Bhubaneswar, Odisha. Adv Res J Multidisc Disco. 2021;57(1):01-06.

94. Datta SC. Animal-Biomedicines Prevent Disease of Tomato and Coronavirus-Like-Pandemic-Diseases: Enriched Agriculture SocioEconomy Science-Technology-Communication-Issues. Merit Research Journal of Microbiology and Biological Sci. 2021;9(3):1-4.

95. Liu C, Shi W, Becker S, et al. Structural basis of mismatch recognition by a SARS-CoV-2 proofreading enzyme. Sci. 2021; eabi9310:1-10.

96. Datta SC. Genes of Gall 200C and Nematode 200C May Develop Biomedical Vaccines Against Plants and COVID-19 Diseases: Advanced Medical Science Technology Agriculture Health Issues. Journal of Biomedical and Life Sciences. 2021;1(1):22-37.
97. Datta SC. Genetic Effects of Ultra-High-Diluted-Biomedicines Gall 30C, Gall 200C, and Gall 1000C May Be a Vaccines Against Plant and COVID-19 Diseases: Improved Agriculture-Health-MedicalPharmaceutical-Science-Technology-Communication-Issues. Journal of Drug Research and Development. 2021;7(2).

98. Datta SC. Biomedicines Improved Food-Security Sustainability Agriculture-Biodiversity Socio-Economy ScienceTechnology-Communication: Preventing Root-Callus, Plant-Diseases and COVID-19. LJMHR London Journals Press. 2021;21(4).

99. Datta SC. 21 $1^{\text {st }}$-Century Preventive Non-Medical-COVID19-StudentsNGO- Model. $1^{\text {st } e d n . ~ L A P ~ L A M B E R T ~ A c a d e m i c ~ P u b l i s h i n g, ~ E d i t o r: ~}$ ljardan, 2021;p 100.

100. Datta SC. Bats Act as a Natural-Booster-Family-Vaccine-Immunization Against COVID-19: Provide Preventive-Family-Health-Care-HealthRisk-Services-Healthy-Lifestyle Enriched-Wildlife-ConservationAgriculture-Forestry-Science-Technology-Communication-ApplicationIssues. Journal of Family Medicine. 2021;8(9):1279.

101. Datta SC. Bats Act as a Natural-Booster-Community-Vaccine Against COVID-19. IASR Journal of Medical and Pharmaceutical Science (IJMPS). 2021;1(2):13-25.

102. Datta SC. Wildlife Conservation Act as Future Clinical-Medical ImagesCase Reports of COVID-19 Model: Enriched Forestry-HorticultureAgriculture-Environment-Health-Biodiversity-Medical-ScienceTechnology-Communication-Application-Issues. Journal of Clinical and Medical Images, Case Reports. 2021;1(1):1033.

103. Datta SC. Owls and Bats Act as Future 'Wild X-Disease' Preventive COVID-19 Non-Medicated Vaccine: Improved Global-Health-ForestryAgriculture-Environment-Science-Technology-Communication. Global Journal of Science Frontier Research: C Biological Science (GJSFR-C). 2021;21(5).

104. Datta SC. Wildlife-Owl-Conservation May be Immunized-Community Against 'Future-Disease-X': Provide Clue Clinical-BiomedicalResearch Global-Health-Enriched-Biodiversity-Forestry-AgricultureEnvironment-Science-Technology-Communication-Issues. Aditum Journal of Clinical and Biomedical Research. 2021;6(2):022-036. 